\title{
The Effectiveness of Law Enforcement on Illegal Logging Based on the Value of Justice
}

\author{
Diding Rahmat \\ Faculty of Law, Universitas Kuningan, Indonesia \\ E-mail: didingrahmat@uniku.ac.id
}

How to cite : Rahmat, Diding."The Effectiveness of Law Enforcment on Illegal Logging Based on the Value of
Justice". UNIFIKASI : Jurnal Ilmu Hukum. 7(1). 2020. 28-34. DOI : 10.25134/unifikasi.v7i1.2715
$\begin{array}{lll}\text { Submitted : 14-01-2020 } & \text { Revised : 07-04-2020 } & \text { Accepted : 16-04-2020 }\end{array}$

\begin{abstract}
Forests are the lungs of the earth that contribute to environmental balance. In practice, the enforcement of environmental law through various regulations, such as Forestry Law, has brought both positive and negative impacts. This study aims to find out the regulations on illegal logging and to identify the effectiveness of law enforcement on illegal logging based on the value of justice. This study was conducted in Kuningan District Regional Government, Ciremai Mountain National Park (TNGC), Kuningan District Forestry Service, Kuningan District Court, Kuningan District Police Office, and Kuningan District Prosecutors Office. This qualitative study applied an empirical juridical or socio-legal approach in order to find data relating to law enforcement on illegal logging as well as preventive and repressive actions based on justice values carried out by law enforcement officials in Kuningan District. The results showed that Illegal logging is regulated in Law No. 41 of 1999 concerning Forestry and Law No. 18 of 2013 concerning Prevention and Eradication of Forests Destruction as well as the Supreme Court Circular No. 01 of 2008 concerning Guidelines for Handling Forestry Criminal Cases. Yet, there is no Kuningan District regulation that specifically regulates illegal logging. Further, the effectiveness of law enforcement on illegal logging in Kuningan District can be seen in terms of its legal substance, structure and culture.
\end{abstract}

Keywords: Law Enforcement; Illegal Logging; Value of Justice.

\section{Efektivitas Penegakan Hukum Illegal Logging Berbasis Nilai Keadilan}

Abstrak : Hutan merupakan paru paru dunia yang berkontribusi terhadap keseimbangan lingkungan. Penegakan hukum lingkungan melalui berbagi regulasi seperti undang undang kehutanan telah banyak memiliki nilai positif dalam prakteknya, akan tetapi juga ada nilai negatifnya Peneliti melakukan penelitian yang berjudul "Efektivitas Penegakan Hukum Illegal Logging Berbasis Nilai Keadilan (Studi Di Kabupaten Kuningan) " Lokasi penelitian dilakukan Kabupaten Kuningan yaitu pemerintah Daerah Kabupaten Kuningan, TNGC, Dinas Kehutanan Kabupaten Kuningan, Pengadilan Negeri Kuningan, Kepolisian dan Kejaksaan Negeri Kuningan. Tujuan penelitian adalah untuk mengetahui pengaturan mengenai illegal logging saat ini serta bagaimana penegakan hukum illeggal loging Kabupaten Kuningan. Metode yang dipakai oleh peneliti dalam penelitian ini adalah metode kualitatif dengan pendekatan yuridis empiris atau sosio legal dengan cara melakukan penelitian lapangan untuk mencari data mengenai penegakan hukum illeggal logging di Kabupaten Kuningan serta tindakan preventif dan represif yang dilakukan oleh aparat hukum berbasis nilai keadilan. Hasil Penelitian yaitu pengaturan Illegal logging diatur dalam Undang Undang Undang Undang No.41 Tahun 1999 Tentang Kehutanan dan Undang Undang No.18 Tahun 2013 Tentang Pencegahan dan Pemberantasan dan Perusakan Hutan sedangkan dalam peraturan lainya juga terdapat dalam Surat Edaran Mahkamah Agung No.01 Tahun 2008 Tentang Petunjuk Penanganan Perkara Tindak Pidana Kehutanan Sedangkan di Kabupaten Kuniningan belum ada perda tentang Illegal logging, Selanjutnya Efektivitas penegakan hukum illegal loging di Kabupaten Kuningan berdasarkan hasil penelitan dapat dilihat Dewan Perwakilan Rakyat

Kata Kunci: Efektivitas; Penegegakan Hukum; Ilegal Loging; Keadilan.

\section{INTRODUCTION}

In a state based on the rule of law, such as Indonesia, law enforcement is an effort to realize the legal ideas and concepts expected by the community. Law enforcement is a process that involves various aspects. ${ }^{1}$ The legal ideas and concepts expected by the community refer to the creation of justice, prosperity as well as public order and peace as mandated by the Preamble to the 1945

\footnotetext{
${ }^{1}$ Dellyana,Shant.1988,Konsep Penegakan Hukum. Yogyakarta: Liberty hal 32
} 
Constitution of the Republic of Indonesia. Law enforcement in Indonesia seems to be far from expectation. The weakness of legal apparatus in law enforcement efforts, the lack of public legal awareness, and the inappropriate legislation philosophically and sociologically as it contradicts with local culture and is only based on juridical aspects are some of the legal problems faced in Indonesia. Conversely, law enforcement shall not be only based on a juridical aspect, but shall also be complemented by socio-political and socio-cultural aspects. ${ }^{2}$

In its function as a protection of human interests, law has goals to be achieved. The main goal of law is to create public order and peace. With the creation of public order, it is expected that human interests can be protected. In achieving its goals, law has the duties to divide individual rights, obligations and authorities in community as well as to regulate legal problem solving and legal certainty. ${ }^{3}$ Article 33 Paragraph (3) of the 1945 Constitution of the Republic of Indonesia states that the land and the waters as well as the natural resources therein shall be under the powers of the state and shall be used to the greatest benefit of the people. Further, Article 33 Paragraph (4) of the 1945 Constitution of the Republic of Indonesia declares that the organization of the national economy shall be conducted in the basis of economic democracy upholding the principles of togetherness, efficiency with justice, continuity, environmental perspective, and self-sufficiency as well as keeping a balance in the progress and unity of the national economy. ${ }^{4}$

Based on Article 33 of the 1945 Constitution of the Republic of Indonesia, it is clear that the management of natural resources by the state shall be used to the greatest benefit of the people, while the management of national economy shall be conducted in the basis of economic democracy by upholding the principle of efficiency with justice and prioritizing environmental balance. The management of natural resources often prioritizes the state or business profits without thinking about the consequences for the surrounding environment and/or the surrounding people. In the management of forests or plantations by the state or by the private sector, law enforcement is often subjective and does not provide a sense of justice for small people. For example, there are many farmers who are imprisoned because they take or cut down threes in state or private forest areas. This condition is quiet different from business actors who commit large-scale illegal logging, but they are not imprisoned as the law does not work for them. Based on the results of various studies conducted by environmental and forestry experts, natural disasters are one of the results of forest damage caused by illegal logging. In addition to natural disasters, illegal logging also causes the damage to flora and fauna and the extinction of endangered species. ${ }^{5}$

Forest damage, according to Law No. 41 of 1999 in the explanation of Article 50 paragraph (2), "shall be the occurrence of physical changes, the physical or biological characteristics of which caused the forest to be disturbed or cannot perform its functions." Meanwhile, the criminal provisions of illegal logging are regulated in Article 78 of Law No. 41 of 1999 concerning Forestry. Forest damage is the basis of the existence of illegal logging. ${ }^{6}$

The term 'illegal logging' comes from English. In 'The Contemporary English-Indonesian Dictionary', the word 'illegal' means forbidden by or contrary to law. Similarly, in the 'Black's Law Dictionary', the word 'illegal' means forbiden by law or unlawfull. Meanwhile, the word 'log' means woods or wooden logs, and the word 'logging' means cutting down trees and bringing logs to the sawn. $^{7}$

\footnotetext{
${ }^{2}$ Muladi, Kapita Selekta Sistem Peradilan Pidana, UNDIP, Semarang, 1995, p.21

${ }^{3}$ Sudikno Mertokusumo, Mengenal Hukum (Suatu pengantar), Liberty, Yogyakarta,1999, p. 71

${ }^{4}$ Suwari Akhmaddhian, Hukum Konservasi Sumber Daya Air, Edukati Press, Kuningan, 2019. p. 4.

${ }^{5}$ Emil Salim, Ratusan Bangsa Merusak Satu Bumi, Buku Kompas, 2007, pp. 23-28

${ }^{6}$ Bambang Tri Bawono dan Anis Mashdurohatun, S, Jurnal Hukum Vol XXVI, No. 2, Agustus 2011, pp. 590611

${ }^{7}$ Salim, Kamus Indonesia Inggris, Modern English Press, Jakarta, 1987 p. 925
} 
Hence, based on the description, it can be concluded that forest damage is the occurrence of physical changes, the physical or biological characteristics of which caused the forest to be disturbed or cannot perform its functions. Hence, the question is that whether or not taking or cutting down trees in the forest can be categorized as damaging the physical characteristics of the forest. This is something that is often ignored by law enforcement officials in carrying out their duties so that farmers are the ones who are often imprisoned because of their need for wood as material for their livelihood. The number of illegal logging cases in Indonesia, especially in Kuningan District, indicates that the implementation of illegal logging law has not been running optimally. Besides, there is a question whether the principles of criminal justice system applied by the law enforcement officials is substantive justice or formalist/procedural justice. Therefore, the author is interested in finding out the current regulations on illegal logging as well as identifying the effectiveness of law enforcement on illegal logging based on the value of justice.

\section{RESEARCH METHODS}

This qualitative study applied an empirical juridical or socio-legal approach in order to find data relating to law enforcement on illegal logging as well as preventive and repressive actions based on justice values carried out by law enforcement officials in Kuningan District.

\section{RESULTS AND DISCUSSION}

\section{A. The Regulations of Illegal Loging}

Basically, the legislations do not explicitly define the term 'illegal logging'. However, the term 'illegal logging' can be seen from its literal meaning. In 'The Contemporary English-Indonesian Dictionary', the word 'illegal' means forbidden by or contrary to law. Similarly, in the 'Black's Law Dictionary', the word 'illegal' means forbiden by law or unlawfull. Meanwhile, the word 'log' means woods or wooden logs, and the word 'logging' means cutting down trees and bringing logs to the sawn. In general, the term 'illegal logging' implies forestry-related activities involving felling, transporting, processing as well as buying and selling logs (including export-import) that are illegal or contrary to the applicable law. Simply, illegal logging can be defined as an activity that can cause forest damage. ${ }^{8}$ Illegal logging is the activities of felling, transporting, processing and selling logs which do not have a permit from the local authority. Besides, the practice of illegal logging can also occur during the transportation, such as giving false information to customs in the export process, before logs are sold on legal market. ${ }^{9}$

According to Mulyatno, criminal act is an act prohibited by a rule of law which is accompanied by a criminal threat (sanction) for those violating the rule. In this case, there are 3 (three) things to note: ${ }^{10}$

a. Criminal act is an act that is prohibited by law and is threatened by a criminal threat (sanction)

b. A condition or an event is a result of a person's behavior. Hence, a criminal threat is addressed to the person caused the event, while a prohibition is addressed to an action.

c. There is a close relationship between prohibition and criminal threat. In this case, an event cannot be prohibited if the one causing the event is not a person and the person cannot be threatened with a criminal threat unless because of the event that caused them.

\footnotetext{
${ }^{8}$ Fransiska Novita Eleanora, Tindak Pidana Illegal Logging Menurut Undang-Undang Nomor 32 Tahun 2009 Tentang Perlindungan Dan Pengelolaan Lingkungan Hidup, Adil : Jurnal Hukum Vol. 3 No.2, pp. 217-238

${ }^{9}$ Indro Sugianto, Manual Investasi Illegal Logging, Indonesian Center For Environmental Law, Jakarta,2006, pp. $15-18$

${ }^{10}$ Diding rahmat, pengantar hukum pidana, Edukati press, kuningan,2018, p. 21
} 
Criminal acts in forestry sector can be classified into 3 groups, namely; 1) prohibition on damaging facilities and infrastructure of forest protection; 2) prohibition on causing forest damage; and 3) administrative prohibitions that provide criminal sanctions. ${ }^{11}$ There are three aspects in law enforcement on forestry that cannot be separated as they are part of the legal system, namely; 1) legal substance which is regulated and stated in Law No. 41 of 1999 and other legislations relating to Forestry Law; 2) legal structure which involves law enforcement officials, starting from investigators, public prosecutors, judges (including ad hoc judges), and legal advisors; whether or not law enforcement officials have worked based on their respective duties and authorities as well as whether or not they have coordinated well as a part of the integrated criminal justice system; and 3) legal culture which is related to the role of the society, either individuals, social groups, community organizations, non-governmental organizations, and universities in law enforcement on forestry. ${ }^{12}$

Article 33 of the 1945 Constitution of the Republic of Indonesia is one of the laws governing the definition of the economy, the utilization of natural resources, and the principles of national economy. Article 33 of the 1945 Constitution of the Republic of Indonesia states that; Paragraph (1) - the economy shall be organized as a common endeavor based upon the principles of the family system; Paragraph (2) - sectors of production which are important for the country and affect the life of the people shall be under the powers of the state; Paragraph (3) - the land and the waters as well as the natural resources therein shall be under the powers of the state and shall be used to the greatest benefit of the people; Paragraph (4) - the organization of the national economy shall be conducted in the basis of economic democracy upholding the principles of togetherness, efficiency with justice, continuity, environmental perspective, and self-sufficiency as well as keeping a balance in the progress and unity of the national economy; Paragraph (5) - further provisions relating to the implementation of this article shall be regulated by law.

Thus, it is clear that Article 33 paragraph (1), (2), (3), (4), and (5) of the 1945 Constitution of the Republic of Indonesia regulates the basic rules of the government, as well as the people, that include various matters from the simple things to the more complex things concerning the people's lives. Article 33 of the 1945 Constitution of the Republic of Indonesia describes the basis of economic democracy in which the production is carried out by and for the people under the leadership or supervision of community members. Thus, it is clear that economic democracy prioritizes public prosperity, not someone's prosperity. Further, Article 33 Paragraph (3) states "the land and the waters as well as the natural resources therein shall be under the powers of the state and shall be used to the greatest benefit of the people". Thus, it can be concluded that Article 33 of the 1945 Constitution of the Republic of Indonesia strictly prohibits the control of natural resources under the power of individuals or certain parties. In other words, monopoly, oligopoly and cartel practices in the management of natural resource contradict with the principle of Article 33 of the 1945 Constitution of the Republic of Indonesia. The sentence 'under the powers of the state' in paragraphs (2) and (3) is not always interpreted in the form of ownership, but mainly in the form of the ability to control and regulate companies to hold to the principle of public interests and prosperity. Article 33 of the 1945 Constitution of the Republic of Indonesia which is based on a social spirit places the control of natural resources in the public interest. This is based on the assumption that the government has a mandate to carry out state life in Indonesia. Therefore, the holder of this mandate should have legitimacy. Besides, there should someone who controls in order to know whether or not the party is honest, fair, accountable, and transparent. Further, Illegal Logging is also regulated in Law No. 41 of 1999 concerning Forestry and Law No. 18 of 2013 concerning Prevention and

\footnotetext{
${ }^{11}$ Ernest Runtukahu, Hambatan Dan Upaya Pembenahan Penegakan Hukum Terhadap Kejahatan Di Bidang Kehutanan, lex Et Societatis, Vol. Ii/No. 2/Februari/2014, p.63

${ }^{12}$ Ibid, p.63
} 
Eradication of Forests Destruction as well as the Supreme Court Circular No. 01 of 2008 concerning Guidelines for Handling Forestry Criminal Cases.

\section{B. The Effectiveness of Law Enforcement on Illegal Logging in Kuningan District}

Law enforcement based on the value of justice requires a balance between the offender and the victim in restoring the victim's rights. Meanwhile, criminal law enforcement requires the accountability of the offender for his crimes that have harmed the public interest. Hence, in this context, there must be a middle ground to mediate between justice and criminal law enforcement, especially in the case of illegal logging. Based on the collected data on illegal logging cases in the police, prosecutors and court offices in Kuningan district jurisdiction, there were 3 cases of illegal logging on July-December 2018 and 2 cases in 2019. ${ }^{13}$ The effectiveness of law enforcement on illegal logging based on the value of justice is describe below.

1. Legal Substance

Basically, the regulations governing illegal logging in Indonesia are fairly good. Yet, flexibility is needed in the articles that protect the interests of forest farmers who only take wood on a small scale for personal use or household needs. Hence, a legal breakthrough is needed in terms of discontinuing the criminal proceedings of the farmers so that there will be no more criminalization towards forest farmers, such as the case of Mpok Minah in Purwokerto Banyumas, the case of Ujang in Kuningan District, etc.

The case of a farmer, who steals only one stick of wood for personal use and receives a heavy sentence that is a threat of at least one year imprisonment, indicates the need to reconstruct the regulations on illegal logging substantively so that there is justice for small communities. Besides, an active participation of the local government is also needed in formulating regulations on illegal logging which is expected to minimize the number of criminalization cases that may occur in Kuningan District.

\section{Legal Culture}

The lack of legal awareness of the community and the officials in protecting and preserving the forest indicates the needs for socialization and training on illegal logging, especially in Kuningan District. The regional government policy on water resources conservation is stated in Kuningan District Regulation No. 12 of 2007 concerning Conservation of Water Resources. The success of the government's efforts to improve public legal awareness in Kuningan District is seen from the protests done by the community when the local government cut down tree in Cilimus Market. The conclusion is that the regional government policy on the conservation of water resources has been effective to increase public awareness in environmental conservation. However, innovations to increase public awareness are needed, such as holding cleanliness contests at sub-district or village level and exploring the potential of local wisdom to improve public environmental awareness. ${ }^{14}$

\section{Legal Structure}

Legal structures involve all legal apparatus, namely police, forest police, prosecutors, advocates, and judges handling illegal logging cases. In practice, legal apparatus sometimes focuses solely on the law, even though it is also recommended to prioritize customary law. In this regard, it is hoped that the regional government can optimize the legal aid program that can be used to assist forest farmers in dealing with legal issues related to illegal logging. The legal aid program is a litigation and non-litigation legal service program provided by legal aid providers to legal aid recipients for free. Its

\footnotetext{
${ }_{14}^{13}$ Source: Kuningan District Court

${ }^{14}$ Suwari Akhmaddhian, Pengaruh Kebijakan Pemerintah Daerah Dalam Konservasi Sumber Daya Air Terhadap Kesadaran Lingkungan Masyarakat Kabupaten Kuningan , Jurnal Unifikasi, ISSN 2354-5976 Vol. 04 Nomor 01 Januari 2017 ,p.1
} 
implementation must be based on the principles of justice, equality before the law, openness, efficiency and effectiveness as well as accountability. Kuningan District is one of the Districts in West Java that has a legal aid program for disadvantaged people. The program is a result of the collaboration between Kuningan District Government, Court, Prosecutors, Police and an accredited Legal Aid Organization in West Java. The program has been started since 2014. ${ }^{15}$

\section{CONCLUSION}

Based on the analysis, it can be concluded that: Illegal logging in Indonesia is regulated in Law No. 41 of 1999 concerning Forestry, Law No. 18 of 2013 concerning Prevention and Eradication of Forests Destruction and the Supreme Court Circular No. 01 of 2008 concerning Guidelines for Handling Forestry Criminal Cases. The effectiveness of law enforcement on illegal logging in Kuningan District can be seen in terms of its legal substance, structure and culture, namely: Substantially, there is a need for regional regulations governing illegal logging based on the value of justice; Structurally, in law enforcement practices, the law enforcement officials do not only have to consider the existing regulations, but also have to consider local wisdom; Culturally, there is a need for socialization and training on illegal logging so that the community can actively participate in protecting and preserving the forest.

\section{SUGGESTION}

Based on the aforementioned conclusions, the following suggestions are proposed: There needs to be a change in legislation that is based on the value of justice and emphasizes the aspect of administrative punishment and There needs to be an improvement in terms of legal culture and structure through socialization and training.

\section{REFERENCES}

Akhmaddhian, Suwari. Hukum Konservasi Sumber Daya Air. Kuningan : Edukati Press, 2019.

Akhmaddhian, Suwari. "Pengaruh Kebijakan Pemerintah Daerah Dalam Konservasi Sumber Daya Air Terhadap Kesadaran Lingkungan Masyarakat Kabupaten Kuningan" Jurnal Unifikasi, Vol. 04 No. 01. 2017.

Bawono, Bambang Tri dan Anis Mashdurohatun. "Penegakan Hukum Pidana Di Bidang Illegal Logging Bagi Kelestarian Lingkungan Hidup Dan Upaya Penanggulangannya”. Jurnal Hukum Vol XXVI, No. 2, Agustus 2011

Dellyana,Shant. Konsep Penegakan Hukum. Yogyakarta: Liberty, 1988.

Eleanora, Fransiska Novita. "Tindak Pidana Illegal Logging Menurut Undang-Undang Nomor 32 Tahun 2009 Tentang Perlindungan Dan Pengelolaan Lingkungan Hidup". Adil : Jurnal Hukum Vol. 3 No.2.2012.

Mertokusumo, Sudikno. Mengenal Hukum (Suatu Pengantar). Yogyakarta : Liberty, 1999.

Muladi. Kapita Selekta Sistem Peradilan Pidana. Semarang : UNDIP, 1995.

Rahmat, Diding. Pengantar Hukum Pidana. Kuningan : Edukati Press, 2018.

Rahmat, Diding. "Implementasi Kebijakan Program Bantuan Hukum Bagi Masyarakat Tidak Mampu Di Kabupaten Kuningan”. Jurnal Unifikasi, Vol. 04 No. 01.2017

Runtukahu, Ernest. " Hambatan Dan Upaya Pembenahan Penegakan Hukum Terhadap Kejahatan Di Bidang Kehutanan”. Lex Et Societatis, Vol. II/No. 2/Februari/2014.

${ }^{15}$ Diding Rahmat, Implementasi Kebijakan Program Bantuan Hukum Bagi Masyarakat Tidak Mampu Di Kabupaten Kuningan,Jurnal Unifikasi, ISSN 2354-5976 Vol. 04 Nomor 01 January 2017,p.39 
Soekanto, Soerjon. Pengantar Penelitian Hukum. Jakarta : UI Press, 1989.

Soekanto, Soerjono dan Sri Mamudji. Penelitian Hukum Normatif, Suatu Tinjaun Singkat. Jakarta : Rajawali, 1985.

\section{Legislations}

The Constitution of the Republic of Indonesia of 1945.

Law No. 41 of 1999 concerning Forestry.

Law No. 18 of 2013 concerning Prevention and Eradication of Forests Destruction.

Law No. 01 of 2008 concerning Guidelines for Handling Forestry Criminal Cases. 